\title{
PELAKSANAAN SUPERVISI OLEH KEPALA SEKOLAH UNTUK MENINGKATKAN KINERJA GURU
}

Oleh

Mutiara Islami Putri 17002020

Email : mutiaraislami2017@gmail.com

\begin{abstract}
Abstrak
Penelitian ini dilaksanakan untuk mengetahui bagaimana pelaksanaan supervisi di sekolah, dan mengetahui bagaimana kinerja guru setelah diadakan supervisi. Penelitian ini dilakukan dengan menggunakan pendekatan deskriptif dengan metode kualitatif. Hasil penelitian menunjukan terdapat beberapa masalah dalam melaksanakan supervisi di sekolah, sehingga sangat diperlukan sekali supervisi untuk meningkatkan kinerja guru. Kepala sekolah mempunyai tanggung jawab untuk meningkatkan kinerja guru dalam mengelola pembelajaran di sekolah, oleh karena itu sangat diperlukan sekali prinsip dan pendekatan agar dapat melakukan supervisi dengan baik.
\end{abstract}

\section{A. Latar Belakang}

1. Pentingnya Supervisi

Supervisi pendidikan di sekolah merupakan upaya pembinaan yang dilakukan oleh kepala sekolah terhadap guru dalam upaya meningkatkan kinerja guru dalam proses pembelajaran, supervisi dilakukan untuk menciptakan proses pembelajaran yang efektif dan juga membantu guru agar dapat memaksimalkan pekerjaannya dalam mambantu peserta didik memecahkan permasalahan dan membantu proses pembelajaran peserta didik.

Supervisi pendidikan berkembang seiring perkembangan ilmu manajemen sebagaimana dikemukakan oleh Sabandi (Sabandi, 2013) Pada awal perkembangannya, supervisi dilakukan dengan pendekatan inspeksi. Supervisor datang ke sekolah dan mengamati guru mengajar. Fokus perhatian supervisor adalah menemukan kesalahan berdasarkan standar kerja baku yang dirumuskan sedemikian rupa oleh otoritas pendidikan. Guru melaksanakan tugas sesuai dengan prosedur operasional yang standar. Supervisor dengan guru merupakan dua pihak sebagai atasan Supervisor memiliki tingkat kebenaran yang lebih tinggi dari pada guru 
Kepala sekolah dalam melakukan supervisi diperlukan suatu keterampilan konseptual, teknikal dan interpersonal dan juga harus memahami konsep suprervisi yang meliputi pendekatan, fungsi, prinsip dan sebagainya sehingga dalam melaksanakan supervisi kepala sekolah dapat dengan mudah karena ia sudah mempunyai pemahaman dan keterampilan.

Dalam melaksanakan supervisi, tentu saja kepala sekolah dihadapkan pada suatu permasalahan atau kendala-kendala. Kepala sekolah harus siap menerima setiap permasalahan yang dihadapi saat melaksanakan supervisi. Adapun masalah yang dihadapi saat melaksanakan supervisi adalah kurangnya motivasi dari para guru ketika mendapatkan supervisi dari kepala sekolah dan kurangnya persiapan guru yang akan disupervisi.

2. Rumusan Masalah

Bagaimana tindak lanjut yang seharusnya dilakukan oleh kepala sekolah dalam meningkatkan kinerja guru sehingga proses pembelajaran dapat berjalan efektif, sementara masalah yang dihadapi oleh kepala sekolah adalah kurangnya kesiapan dan persiapan dari guru yang akan di supervisi.

3. Tujuan Pembahasan

Jurnal ini dibahas dengan tujuan untuk mengetahui bagaiamana pelaksanaan supervisi yang dilakukan oleh kepala sekolah dan untuk mengetahui bagaimana meningkatkan kinerja guru melalui supervisi.

B. Pembahasan

1. Ringkasan Artikel

Supervisi adalah suatu aktivitas pembinaan yang dilakukan oleh kepala sekolah untuk membantu para guru dan pegawai lainnya dalam melakukan pekerjaan mereka dalam proses pembelajaran secara efektif. Supervisi yang dilaksanakan oleh kepala sekolah menggunakan metode deskriptif dengan pendekatan kualitatif. Pelaksanaan supervisi dilakukan sesuai dengan jadwal yang telah ditentukan melalui teknis rapat guru, observasi kelas, dan percakapan pribadi antara supervisor dengan objek yang di supervisi.

Dalam melaksanakan supervisi diperlukan pendekatan supervisi yaitu supervisi klinis. Supervisi klinis yaitu supervisi yang mengembangkan kemampuan guru agar dapat bertanggung jawab terhadap kinerja mereka serta terbuka kepada orang lain. Supervisi klinis dilakukan dalam bentuk proses tatap muka yang memungkinkan 
supervisor dan guru bersama-sama membahas dan menganalisis masalah pembelajaran yang terjadi di kelas.

Adapun masalah yang ditemukan oleh kepala sekolah dalam melaksanakan supervisi yaitu kurangnya persiapan dari para guru yang akan disupervisi, kondisi seperti ini dianggap bahwa motivasi dari guru tersebut masih kurang dikarenakan masih melekatnya anggapan dari para guru bahwa supervisi dilakukan hanya sematamata untuk mencari kesalahan. Dari permasahan seperti itu, kepalas sekolah selaku orang yang melaksanakan supervisi harus melakukan pendelegasian wewenang kepada guru-guru senior, memberikan motivasi yang lebih kepada guru bahwasanya supervisi ini sangat penting dilakukan untuk menilai kinerja guru, pemberian motivasi ini dapat diakukan oleh kepala sekolah dengan cara memberikan pengarahan kepada guru atau mengadakan workshop, rapat, lokakarya bahkan bisa memberikan motivasi secara langsung kepada guru tersebut.

2. Kajian Analitis

Kepala sekolah dalam upaya meningkatkan kinerja guru dapat dilakukan melalui berbagai macam upaya. Salah satunya adalah dengan mengadakan program supervsi pendidikan. Supervisi pendidikan ini tidak hanya difokuskan pada guru bidang strudi atau guru kelas saja namun juga harus menyeluruh terhadap komponen yang ada disekolah tersebut. Adapun pembiaan yang dilakukan adalah dengan memberikan kesempatan kepada guru dalam mmengikuti pelatihan-pelatihan yang ada yang sesuai dengan bidangnya.

\section{Kesimpulan dan Saran}

1. Kesimpulan

Kegiatan supervisi pendidikan yang dilakuakn oleh kepala sekolah terhadap guru di sekolah pada akhirnya adalah akan berujung pada tujuan menciptakan kinerja guru yang baik. Dalam upaya menciptakan cita-cita itu dari pihak pendidik juga sangat diperlukan adanya pembinaan melalui kegiatan supervisi ini. Dimana kepala sekolah sebagai seorang supervisor mengamati kinerja yang dihasilkan oleh para pendidik dan kontribusinya dalam upaya membantu mewujudkan cita-cita pendidikan tersebut. Supervisi terhadap guru termasiuk salah satu cara yang tepat. Karena dengan adanaya supervisi terhadap guru ini lebih mamantapkan konsep tentang apa saja tanggung jawab yang seharusnya dilakukan oleh seorang guru melalui pembinaan-pembinaan. 
2. Saran

Sebaiknya guru di sekolah harus mempersiapkan diri sesiap mungkin sebelum dilaksanakan supervisi. Meskipun pelaksanaan supervisi yang akan dilakukan oleh kepala sekolah dilakukan dengan pemberitahuan terlebih dahulu, alangkah baiknya setelah pemberitahuan tersebut guru dapat mempersiapkan diri dengan matang.

\section{Referensi}

Sabandi, A. (2013). Supervisi Pendidikan Untuk Pengembangan Profesionalitas Guru Berkelanjutan. Pedagogi, Jurnal Ilmiah Ilmu Pendidikan, XIII(2), 1-9. Retrieved from http://ejournal.unp.ac.id/index.php/pedagogi/article/view/4275 